\title{
Procedures in allergy nursing (specialized outpatient care)
}

\section{Procedury w pielęgniarstwie alergologicznym - system AOS (Ambulatoryjna Opieka Specjalistyczna)}

\author{
Ewa Bodzak, Edyta Krzych-Fałta \\ Department of Prevention of Environmental Hazards and Allergology, Medical University of Warsaw, Poland
}

\begin{abstract}
Procedures in allergy nursing play a critical role in the process of improving practical nursing skills. A nurse's diagnosis and treatment work as regards skin prick tests and allergen-specific immunotherapy is an essential part of nursing work with patients suffering from allergic diseases, which - according to statistics - are becoming epidemic in nature, with allergy being referred to as a disease of the $21^{\text {st }}$ century. The special value of this study is that it proposes certain procedures that should be adhered to at the time of the SARS-CoV-2 pandemic threat. Procedures in allergy nursing play a major role in ensuring the accuracy of all nursing work, which involves skin prick tests and allergen-specific immunotherapy in this case. If such procedures are adhered to, they allow for eliminating medical errors, which may result in adverse events on more than one occasion. At a time when people are exposed to SARS-CoV-2 infection and other pathogens, the procedures are critical to ensuring the safety of nurses and their patients. This is the first such study prepared as a precise, step-by-step description of the rules of the work of allergy nurses. Diagnosis and treatment in the area of allergy nursing should be promoted widely and provided in accordance with accepted procedures.
\end{abstract}

\section{KEY WORDS:}

procedure, skin prick tests, allergen-specific immunotherapy, allergy nurse.

\section{STRESZCZENIE}

Procedury w pielęgniarstwie alergologicznym odgrywają krytyczną rolę w doskonaleniu praktycznych umiejętności pielęgniarki. Wykonywane czynności diagnostyczno-terapeutyczne w obszarze testów skórnych i immunoterapii swoistej stanowią nieodzowny element w pracy z pacjentami obciążonymi chorobami alergicznymi, które jak wynika ze statystyk, przyjmują charakter epidemii i stają się chorobą XXI wieku. Szczególną wartość niniejszego opracowania ma również opracowanie procedur, które powinne obowiązywać w dobie zagrożenia pandemicznego SARS-CoV- 2. Jest to pierwsze tego typu opracowanie, które krok po kroku precyzyjnie opisuje zasady najczęściej podejmowanych czynności przez pielęgniarki alergologiczne.

\section{SŁOWA KLUCZOWE:}

procedura, testy skórne, immunoterapia swoista, pielęgniarka alergologiczna. 


\section{ADDRESS FOR CORRESPONDENCE}

prof. Edyta Krzych-Fałta, Department of Prevention of Environmental Hazards and Allergology,

Medical University of Warsaw, Warsaw, Poland, phone: +48 2259910 40, e-mail: e.krzych@gmail.com

\section{INTRODUCTION}

In nursing, the term procedure is defined to be $a$ description of the actions taken as part of the care provided by a nurse [1]. Moreover, as a way to improve the quality of nursing care, procedures need to be put into practice first, followed by care standards (care models), and these need to be adhered to when delivering care to individual patients $[1,2]$. Furthermore, each procedure "should be based on proven and accepted rules of nursing conduct that meet the expectations of people, reflect the available organisational resources, capabilities, experience, as well as economic and cultural requirements, and the regulatory framework for practising the nursing profession. Each procedure should also reflect the present state of medical and nursing knowledge and reliable scientific contributions, should be implemented in the practice of nursing in accordance with the applicable nursing practice standards and should be described as a logical step-by-step sequence of actions, depending on their complexity, verified in practice and revised at such time as the team for supervising the quality of nursing care may decide" [1].

Procedures in allergy nursing play a major role in ensuring the accuracy of all nursing work, which involves skin prick tests and allergen-specific immunotherapy in this case. If such procedures are adhered to, they allow for eliminating medical errors, which may result in adverse events on more than one occasion. At a time when people are exposed to SARS-CoV-2 infection and other pathogens, the procedures are critical to ensuring the safety of nurses and their patients. This study is the author's original work and a major contribution to the process of improving the skills of allergy nurses.

\section{PROCEDURES AT THE TIME OF SARS-COV-2}

SARS-CoV-2 (severe acute respiratory syndrome coronavirus 2) is classified as a single-stranded RNA virus $((+)$ ssRNA virus) and causes an acute respiratory syndrome known as COVID-19 [3]. As a chimera of two viruses, COVID-19 has claimed thousands of human lives worldwide. Its complex pathogenesis of reactions and the consequences of infection lead to both personal care and public health issues. When dealing with a patient who may or may not be infected by the virus, the utmost care should be taken to minimize the risk of infection. In such a case, epidemiological history taking is necessary and measures should be taken to protect the nurse's and the patient's health (Tables 1,2).

\section{PROCEDURE FOR PERFORMING SKIN PRICK TESTS}

The main objectives of a skin prick test (SPT) procedure are to specify the normal actions taken when performing an SPT, to eliminate the risk of errors when performing an SPT which may affect the results of the test and their interpretation, and to ensure the safety of the patient [4].

\section{GENERAL REQUIREMENTS FOR PERFORMING SKIN PRICK TESTS (SPTS)}

\section{General information}

1. The quality of performing an SPT is one of the essential factors that determine the accuracy of the results of this diagnostic test.

2. SPTs should only be performed in dedicated rooms with appropriate equipment and lighting, with access to a medical emergency kit and the necessary medicines for responding to adverse events.

3. SPTs should be performed by an experienced and trained nurse on the instruction and under the supervision of an allergist.

4. Indications for SPTs. An SPT may be performed:

- to confirm or exclude a person's sensitivity to specific allergens (plant pollen, house dust mites, pet hair or fur, mould spores),

- to choose allergy prevention measures and to determine further action and treatment methods or

- to determine whether a patient qualifies for allergen-specific immunotherapy.

5. SPTs may be given to children aged 3 years or older (or to younger children if the minimum required cooperation is provided to ensure the test is performed properly). No minimum age for SPTs is defined.

6. Before an SPT is performed, the patient must be provided with the necessary information about the purpose of the test and how the patient should prepare for it.

7. Before an SPT is performed, the patient must not have been taking any antihistamines, antidepressants 
TABLE 1. Epidemiological history taking at the time of SARS-CoV-2

\section{EPIDEMIOLOGICAL HISTORY}

Full name:

PESEL [national ID number]:

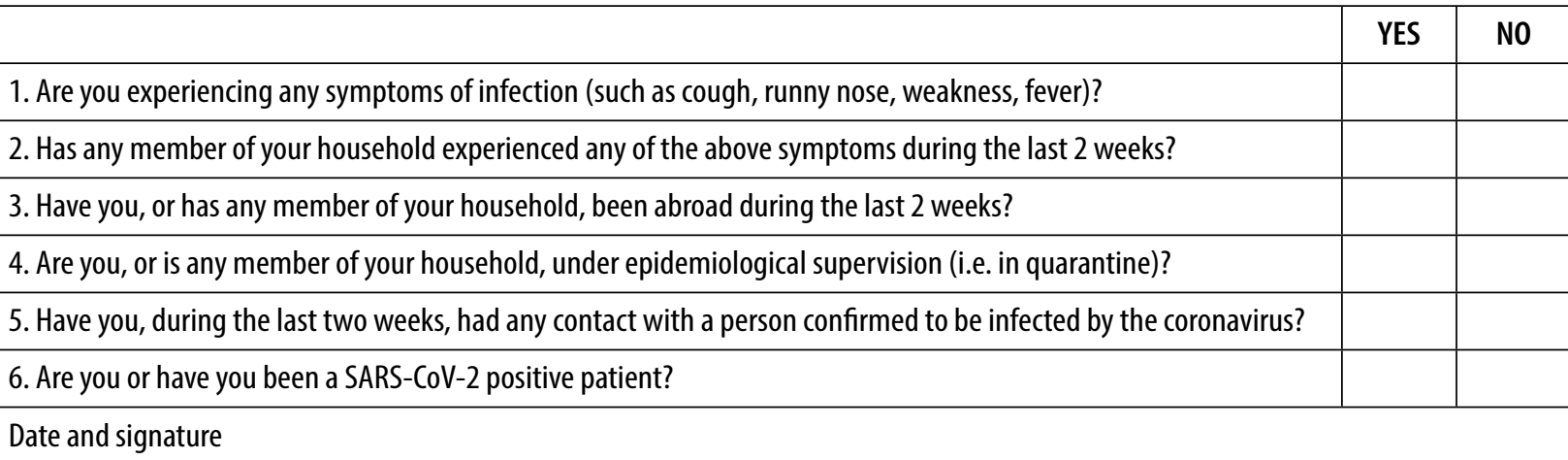

TABLE 2. Instructions for dealing with allergic patients at the time of SARS-CoV-2

\section{The following are the safety instructions to be followed by allergy nurses when performing subcutaneous immunotherapy} (SCIT) vaccinations during the SARS-CoV-2 pandemic.

1. One or two days in advance, provide the Patient Registration Desk personnel with a list of the patients with medical appointments made after medical advice was given to them by telephone. Exclude the patients with risk factors for infection by SARS-CoV-2 and pre-qualify them for vaccination

2. The Patient Registration Desk personnel will prepare the patients' medical records and deliver the list of appointments to the personnel responsible for allowing patients/personnel into the hospital building (using the entrance next to the security guards' office)

3. Each patient entering the hospital must be wearing a face mask

4. Appointments for vaccination must be made with each patient for a specific time slot (a time-based separation policy)

5. A separate room (a treatment room) must be used for vaccination. No person with symptoms of a severe infection may be allowed to enter the room

6. Before a patient is allowed into the treatment room, the nurse must take the patient's temperature, sanitise their hands and give them a pair of gloves that the patient must put on after their hands have been sanitised

7. A patient entering the treatment room must not be wearing any coat or jacket or carrying any unnecessary bags and must be wearing gloves and a face mask (a notice with these requirements must be displayed on the outside of the treatment room door)

8. All necessary personal belongings (such as handbags or jackets) must be left on a chair next to the chair for vaccination

9. Each immunotherapy patient must sit on the blood collection chair, which must be located as close to the treatment room door as possible (to reduce the space for physical contact to a minimum) and which can be sanitised easily

10. The nurse will take a brief history from the patient, prepare the vaccine and fill in the necessary documents at a desk located at least 2 (two) $m$ from the patient (a time-based separation policy)

11. Each patient must expose their arm for injection and turn their head in the direction opposite to the exposed arm

12. The nurse must not offer her pen to the patient to sign any documents. The pen available to the patient must be sanitised each time it has been used

13. Before each injection, the nurse must wash/ sanitise her hands, put on a pair of gloves, a face mask and a pair or protective glasses/ a protective shield

14. Each vaccine ampoule/ pack brought by a patient must be sanitised immediately

15. After performing each injection, the nurse must disinfect the surface of each object that the patient came into contact with (chairs, door handles etc.), remove her gloves safely and dispose them into a red bag located near the area where the medical service was provided, and then wash/ sanitize her hands

16. After the vaccination, the patient must leave the treatment room, keeping a safe distance away from any other patient in the corridor. After $30 \mathrm{~min}$, the patient must knock at the treatment room door. The nurse will open the door and allow the patient into the treatment room, where she will check the injection site exposed by the patient

17. Before the next patient is allowed into the treatment room, the nurse must ventilate the room 
and/or glucocorticoids for one or two weeks before the test (if the dose taken is larger than $10 \mathrm{mg}$ /day in terms of prednisolone) if taken systemically, i.e. orally, intravenously, intramuscularly or subcutaneously, or any glucocorticoid preparations and/or anaesthetics if administered locally to the SPT test area(s).

8. Contraindications against SPTs. An SPT should not be performed if the patient:

- is pregnant (this, however, will depend on the circumstances),

- has poorly controlled asthma and/or pulmonary dysfunction,

- has pathological skin lesions in the areas where the test is to be performed,

- is taking any medicines systemically (antihistamines, steroids - if the dose is larger than $10 \mathrm{mg}$ of prednisolone equivalent),

- is taking steroids and calcineurin inhibitors administered locally,

No patient should be given an SPT within the first 4 weeks of experiencing an anaphylactic shock (false negative result) or within 1 or 2 months of completing a course of phototherapy, or of sun tanning or indoor bed tanning.

9. Only standardised, brand-name allergen extracts for SPTs should be used, if they have been stored properly and before their use-by dates expire.

10. All extract packs should be kept in a refrigerator, at a temperature of $2-8^{\circ} \mathrm{C}$ to prevent their degradation and/or loss of potency. Avoid overheating or freezing allergens.

11. Before performing an SPT, the nurse should take a history from the patient to obtain information about the patient's health and any medications they may be taking.

12. When performing an SPT, the nurse must comply with the rules of asepsis and antisepsis and use techniques that ensure the accuracy of the diagnostic test.

13. Each SPT must be correctly documented in the patient's medical history record and in the treatment room's register of treatments.

\section{Specific requirements for performing skin prick tests}

1. Before an SPT is performed for a patient, the patient must provide a referral letter from a doctor and the identity of the patient must be verified beyond any doubt.

2. A thorough history must be taken by the nurse (Table 3) from the patient before she proceeds with any diagnostic testing in respect of the patient. If the patient is a child, the necessary information should be obtained from the child's parent or other legal guardian.
3. The patient's general health should be good, preferably in remission.

4. An SPT may only be performed in one of the following skin areas without any pathological lesions:

- the volar surface of a forearm $(5 \mathrm{~cm}$ away from the wrist and $3 \mathrm{~cm}$ away from the crook of the elbow),

- the upper part of the back (the region of the shoulder blades, avoiding the spine).

5. The area where the extracts will be applied must be marked precisely to avoid a mistake when applying a patch to the skin and measuring the results.

6. The allergen number must be recorded on the patch, and the patch must be applied to the test area or the allergen number must be provided directly on the skin.

7. Isolated extract drops (approx. $0.05 \mathrm{ml}$ per drop), which should be as similar as possible, must be applied onto the skin, keeping a distance of $2-5 \mathrm{~cm}$ between one drop and another to prevent the drops from mixing, which might make it difficult to measure the result. Drops may be applied in two rows.

8. The application of the drops must be followed by the application of a negative control (the solution that was used to prepare or dilute the allergen extracts) and a histamine positive control (HPC).

9. The histamine positive control must be measured 8-10 min after application. The control is positive if the diameter of the bleb is larger than $3 \mathrm{~mm}$.

10. Use a lancet to apply allergen droplets into the skin, using

- the standard method, i.e. perpendicularly to the surface of the skin, or

- the modified method, i.e. at an angle of $30 / 70^{\circ}$ with the skin lifted up.

11. Prick the skin once at a time, applying the same force and achieving the same depth with each prick, pressing the skin for approx. $1 \mathrm{~s}$, avoiding blood sampling and double pricking for the same droplet.

12. Each disposable droplet lancet should be standardised, preferably with a metal blade of approx. $1 \mathrm{~mm}$, and allowing a pricking depth of approx. $0.4 \mathrm{~mm}$ to be achieved. Alternatively, a plastic lancet with a 1.4-1.6 mm blade can be used (avoid using injection needles or blood lancets).

13. Use a separate lancet for each allergen. Alternatively, the same lancet can be used for different allergens, but only if the lancet has been cleaned carefully to prevent the transfer of allergen between pricks. Each lancet must be disposed of after it has been used.

14. Measure the result of the test after 15-20 min.

Note. The result must be recorded by the same person who performed the SPT.

15. Use a gauze pad to remove the allergen (by drying it gently). 
TABLE 3. Taking a patient history (for nurses)

\section{HISTORY TO BE TAKEN BY THE NURSE}

Date

Patient's full name

PESEL [national ID number]

1. Have you refrained from taking, over the last 7-14 days, any antihistamines, anti-inflammato-
ry drugs, steroids or any other medication that might affect the result of the test?

2. Have you today applied any cream or ointment onto the skin in or around the test area?

3. Are you pregnant?

4. Are you experiencing an exacerbation of allergic symptoms today?

5. Have you suffered an anaphylactic shock in the last four weeks?

6. Have you sunbathed and suffered skin irritation from sunlight in recent days?

7. Have you had an infectious disease in the last 2 weeks?

8. Have you, in the last 14 days, been vaccinated against, for example, flu? (If the patient is a child, refer to the vaccination schedule)

9. Have you eaten anything today?

10. Are you being treated for any chronic diseases?

Signature of the patient and/or the patient's parent or other legal guardian (if the patient is aged 16, the child's signature AND the legal guardian's signature are required).
16. To measure the result of the test, use a transparent ruler with a millimetre scale. Measure the longest diameter (D) of the bleb with red skin around and the diameter perpendicular to it. Calculate the average diameter $((\mathrm{D}+\mathrm{d}) / 2)$.

17. If the diameter of the bleb on the skin at the injection site is $\geq 3 \mathrm{~mm}$, the result is positive.

18. If there is no reaction in the positive control, the result of the test cannot be measured.

19. If the result is negative in the positive control, the result may be difficult to interpret due to excessive dermographism.
20. The result of the test should be recorded on the patient's referral letter. The original referral letter should be handed over to the patient, and a copy of the letter must be included in the patient's medical record file.

21. After the result of the test has been read, close observation of the patient for 30 min must be ensured.

22. Skin reaction areas must be treated with, for example, hydrocortisone (1\%) to alleviate the itching sensation. Administer an antihistamine if requested by a doctor.

23. The clinical interpretation of the result of the test should be performed by a doctor, after taking a history from the patient. 


\section{PROCEDURE FOR ALLERGEN-SPECIFIC IMMUNOTHERAPY}

The main purpose of this procedure for allergen-specific immunotherapy (ASI) is to provide a stepby-step guide to the vaccination process to ensure the quality of the work of nurses in the provision of ASI in accordance with professional standards. This procedure also serves to reduce the risk of the occurrence and/or exacerbation of side effects of specific immunotherapy, to ensure the safety of patients, to define the steps to be taken in the case of adverse events (including anaphylaxis).

\section{IMMUNOTHERAPY REQUIREMENTS}

\section{General information}

1. Patients should be qualified for ASI (based on indications for and contraindications against it), the choice of vaccine made and the starting dose determined by allergists on the basis of appropriate diagnostic management.

2. ASI vaccinations should be performed in designated rooms (i.e. the treatment room on the premises of SPCSK Specialist Outpatient Clinic for Allergy Treatment in Warsaw) by a qualified allergist in cooperation with an experienced nurse.

3. A medical emergency kit, a medical oxygen cylinder and the essential medicines for responding to adverse events should be available in the treatment room.

4. During their qualification meeting with an allergist, the patient should sign their informed consent to the ASI treatment, using the consent form used by SPCSK. The consent document should be included in the patient's medical record file. In addition to the consent statement, the patient should be provided with a copy of the patient information leaflet for the vaccine to be used. A copy of the leaflet must be stapled to the patient's informed consent form. If the patient is a child, the consent of the child's parent or other legal guardian is required; if the child is 16 years old or older, the consent must be given by the child if under the legal age and their parent or other legal guardian.

5. Before the first ASI vaccination, an Immunotherapy Record ("ASI Record") should be created for each patient. The nurse should check that entries in the ASI Record are made correctly and that it has a registration number. The ASI Record must contain the following information: the patient's full name and PESEL (national ID number), the name and composition of the vaccine, the vaccine batch number, the date and the recommended concentration, as well as the allergen extract dose and the details of which arm (left or right) the vaccine is to be given. The ASI Record may include a doctor's instructions or other notes, e.g. information about vaccine reactions.

6. The allergen extract dose should be determined by a doctor separately for each patient.

7. The nurse engaged in ASI should provide educational activities designed to deliver the necessary information about the purpose and principles of ASI throughout the ASI process.

To ensure that the ASI is safe and effective, each patient is expected to cooperate with the ASI personnel by

- strictly complying with the vaccination (ASI) schedule,

- keeping the ASI personnel informed of any changes to their (the patient's) health status, e.g. when another doctor prescribes new medicines for the patient, or when the patient is diagnosed with a new disease, as well as of pregnancy, scheduled preventive vaccinations, vaccine reactions (if any), or if the patient is not feeling well on the AIS vaccination day,

- not leaving the premises of the clinic for $30 \mathrm{~min}$ after vaccination to enable the AIS personnel to check whether any local vaccine reactions and/or adverse systemic reactions have occurred,

- avoiding hot baths, indoor bed tanning, excessive exposure to sunlight, intensive exercise and alcohol for $24 \mathrm{~h}$ after vaccination,

- avoiding the consumption of food products containing histamine, biogenic amines and/or agents that may increase the release of histamine. Such foodstuffs include hard cheese, eggs, smoked meat, fish (tuna, herring, sardine and other tinned products), cocoa, chocolate, fruit (including pickled fruit), sauerkraut, tomatoes, strawberries, coffee or tea,

- Even if the patient's condition improves as a result of ASI, they should avoid exposure to the allergen(s) they are sensitive to.

\section{Specific immunotherapy requirements}

1. After a qualification meeting with an allergist, the patient should go to the treatment room and have their ASI Record, filled in by their doctor, with them.

2. The ASI Record must show the vaccination date, the recommended concentration and the vaccine dose, details of which arm (left or right) the vaccine is to be injected into, as well as the doctor's stamp and signature. A nurse may give the patient an ASI vaccine only on the basis of written instructions from an allergist.

3. The nurse should verify the patient's full name, PESEL (national ID number) and the name of the vaccine, 
and take out the right vaccine, labelled with a waterproof highlighter, out of the refrigerator.

4. The nurse should check that the vaccine taken out of the refrigerator is the one recorded in the patient's ASI Record. Further steps:

- verify the name, composition, batch number and useby date of the vaccine,

- check the current vaccination date, the previous vaccination date and the previous vaccine dose,

- check the recommended vaccine dose and the phial number/concentration details if increasing doses are to be used,

- visually examine the allergen extract (i.e. its colour and clarity).

5. The nurse should ask the patient:

- how they are feeling on the vaccination day,

- if they are experiencing any (exacerbated) allergic symptoms,

- about the extent of any local/systemic reactions following the patient's most recent vaccination,

- about any antihistamines that the patient may have taken before the vaccination (if instructed by their allergist to do so),

- about the date of the patient's previous vaccination to decide whether the dose to be applied should be modified in consultation with a doctor.

6. The nurse should check that the patient is not experiencing herpes and not chewing gum.

7. The patient should be sitting while being given a vaccine.

8. If the patient is a child, the child's parent or other legal guardian (or any other person accompanying the child at the time of the vaccination, with their legal guardian's consent) should be present in the treatment room during the vaccination.

9. The vaccine should be mixed by turning the phial several times carefully. In accordance with the rules of asepsis and antisepsis (use of disposable gloves, sanitising the rubber membrane with spirit), draw the vaccine dose recommended by an allergist into a disposable syringe suitable for precise dosing $(1.0 \mathrm{ml}$ insulin or tuberculin syringe).

10. Sanitise the injection site and apply the vaccine as follows:

- alternating the arms (right/left) into which the vaccine is to be injected,

- deep under the skin (at the angle of $30-45^{\circ}$ ), lifting a skin fold with enough subcutaneous fat with the thumb and index finger,

- into the outer surface of the arm, at half the distance between the shoulder and the elbow, in the depression between the deltoid muscle and the triceps.

11. The vaccine should be administered slowly, holding the cannula at all times while injecting the vaccine, after checking that the vessel is not exposed to light. Aspiration is recommended with every $0.2 \mathrm{ml}$ of the vaccine.

12. Remove the needle, place a sterile gauze pad on the injection site and press the pad for a few seconds to prevent release of the extract or bleeding.

13. Do not massage the injection site.

14. If any blood is aspired, stop injecting and remove the needle. An extract that has come into contact with blood must be disposed of. The patient must be observed closely. If no systemic reaction or strong local reaction occurs after 15-30 min, administer the remaining vaccine dose.

15. If two allergen vaccines are administered to the patient at the same time, the second vaccine should be injected into the other arm 30 min after the injection of the first vaccine if no adverse reaction has occurred as a result of the first injection.

16. After each vaccine injection, the patient must be observed for $30 \mathrm{~min}$ for any local or systemic reactions. The patient should leave the treatment room and wait in the corridor. The patient should be informed that:

- they must stay in the corridor outside the treatment room for $30 \mathrm{~min}$,

- they must not eat anything and/or chew gum within the 30-minute period, and that

- they must report any worrying symptoms immediately. After $30 \mathrm{~min}$, the patient should return to the treatment room to enable the nurse to inspect the injection site and to assess any local reactions.

17. If any local reaction (itching, swelling, redness) has occurred, the nurse must measure the size of the reaction area and apply steroid cream (hydrocortisone (1\%)) and an ice compress onto the area. An antihistamine may be administered to the patient if requested by a doctor. The size of the reaction area and all the steps taken must be noted in the ASI Record.

18. A generalised anaphylactic reaction to a vaccine should always be treated as a direct threat to the patient's life and requires immediate treatment. The treatment should be appropriate to the extent of any clinical symptoms. The rules for dealing with patients, including children, in life- and/or health-threatening situations are described in a separate procedure.

19. The nurse that provides a treatment to the patient should make an appropriate entry in the register of treatments. The entry must include the vaccination date, the patient's ASI Record number, PESEL (national ID number), as well as the name, composition and dose of the vaccine, plus the vaccinating nurse's stamp and signature.

20. The treatment should be documented in the patient's ASI Record as well (with the vaccinating nurse's stamp and signature). 
21. After the vaccination, all used gauze pads must be placed in a red bag, and the syringe and the needle must be placed in a plastic, thick-walled vessel for medical waste.

Any nurse who starts the provision of ASI on a particular day must continue and complete the ASI.

\section{CONCLUSIONS}

Diagnosis and treatment in the area of allergy nursing should be promoted widely and provided in accordance with accepted procedures. Importantly, medical records, including information obtained from the history taken by the nurse from the patient, should be an essential part of any diagnosis and/or treatment process.

\section{CONFLICT OF INTEREST}

The authors declare no conflict of interest.

\section{REFERENCES}

1. Kózka M, Płaszewska-Żwko L. Procedury pielęgniarskie. Podręcznik dla studiów medycznych Wyd. PZWL, Warszawa 2020.

2. Ksykiewicz D (ed.). Zarząazzanie w pielęgniarstwie. Podręcznik dla studentów studiów magisterskich Wydziałów Pielęgniarstwa oraz Wydziałów Nauk o Zdrowiu. Wyd. Czelej, Lublin 2005.

3. https://pl.wikipedia.org/wiki/SARS-CoV-2 (accessed on 6 July 2020).

4. Krzych-Fałta E, Sienkiewicz Z. Przykłady Dobrych Praktyk w Pielęgniarstwie Alergologicznym (POLA). Wyd. Oficyna Wydawnicza Warszawskiego Uniwersytetu Medycznego, Warszawa 2018. 